\title{
Some Issues on Limited Proprietary Rights in the Project of New Edition of the Civil Code of Russian Federation
}

\author{
E. D. Gorevoi ${ }^{1}$ \\ ${ }^{1}$ Civil law department of the South, West State University (Kursk), Russian Federation \\ Correspondence: E. D. Gorevoi, 21 Semenovskaya Str., 67, Kursk, 305000, Russian Federation. Tel: \\ 8-910-312-2650. E-mail: gorevoy_e@mail.ru
}

Received: October 10, 2014 Accepted: November 6, 2014 Online Published: November 15, 2014

doi:10.5539/res.v6n4p127

URL: http://dx.doi.org/10.5539/res.v6n4p127

\begin{abstract}
This paper delves into effective legislation and practice of using it in the sphere of limited proprietary rights. The study describes history of such notions as property, estate, and servitudes in the Roman law, the legislation of Russian Empire, the documents of the USSR, and Civil Code of Russian Federation. The effective Civil Code of Russia, as well as of most of the Western European countries, does not explain the notion of the laws of property. It may cause many misunderstandings, so the Code has to be improved. The paper emphasizes the need of designing the criteria for laws of property. The article describes what kind of scientific work needs to be done for construction of the accurate proprietary rights system. The weak and strong points of the laws in force are highlighted. They are compared to the ones proposed in the project. Also the author analyzes advantages and disadvantages of the new edition of the Russian Civil Code.
\end{abstract}

Keywords: law of property, property, estate, servitude, civil code, Russia

\section{Introduction}

The issues of property right limitation in all times attracted attention of the scientists and practitioners: V. I. Kurdinovskii yet agreed that the civil experts should "historically trace until now the limitation in land and immovable property usage according to the Russian legislation" (Kurdinovskii, 1899). In Russia this issue has not been solved yet, that was intensively caused by the peculiarities of historical development of our country, which comparatively recently recognized the existence of the private property.

Meanwhile, as V. P. Kamyshanskii truly stated that only in the era of Great French Revolution the right of property received the "sacrosanct" status. Presently its sacred character is not spoken about, although its inherence and inviolability are not denied. On the opposite, in the course of time the public consciousness recognized the necessity of enhancement of the social role of the property right (Kamyushankii, 2000), and necessity of its limitation.

\subsection{The History of Regulation of Proprietary Right Limitation}

In the scientific literature the limited proprietary right is usually understood in the order established by law as registered absolute civil right, lying in the possibility of that or another limited relation distinctly determined by the law to use the other's immovable property, as a rule, for own benefits without intermediary actions of its owner (including against his will) (Sukhanov, 2002).

The proprietary rights were developed by the Roman lawyers. The pandect study, in its turn, basing itself on the legal material of Roman law, executed the theoretical argumentation of the rights on the others' items (specified as the limited proprietary rights by it) as the independent civil-legal category, implemented their systematization (Emelkina, 2010).

The first written artefacts of the Russian law didn't include distinct legislative differentiation of such notions, as "property" and "possession", instead only separate elements, which can be related to the proprietary right with certain part of conditionality, were met (Danilova, 2008). Correspondingly, there was no any strict system of limited proprietary rights on the property, and couldn't be.

The appeal to the proprietary right category in Russia took place only in the second half of XIX century. In the Legal civil code of the Russian Empire Section II of book II of volume X was called as "About the essence and 
space of different property rights" and in the rank with property right considered the right of participation in usage and benefits of other's property (in essence, the right of servitude type, established for passing and driving cattle etc.); the right of lands in other's properties (usage of forests according to the "entry right" and hunting right); the right of possession and usage, separate from the property right (life possession of family estate, separate usage of movable property, e.g. lost-property finding) and the disposal right, separate from the property right (assignment of the disposal right under power of attorney, owing to purchase deeds and mortgaged fortresses, sequestration or guardianship) (Legal Code, 1900). However the legal code didn't provide any strict system of property rights that already in that period generated disputes about possibility of relating one or another rights to the number of proprietary or legally binding (The Russian Civil Right, 1864).

The Civil code, prepared instead of it, offered enough strict system of proprietary (patrimonial) rights in the other's property (section IV of book III), based upon the content of the corresponding limited right: the right of hereditary tribute possession (art. 927-941), the right for land mining development that in essence represented the right of emphyteusis type (art. 942-950), the right of usufructural type - using (art. 951-993), servitudes (art. 994-1028), patrimonial issues (art. 1029-1039), pledge and mortgage (art. 1040-1173) (Tyutryumova, 1910).

In the soviet law according to the existing ideology the independent property rights system that was similar only a little to the Roman-German legal order systems was developed. Along with the property right (state, cooperative and private) CC of RSFSR of 1922 admitted two other proprietary rights - the right of real estate development (art. 71-84), closed to the classical superficies, and charging lien (art. 85-105). At that CC of RSFSR of 1922 gave neither classification of the limited proprietary rights, nor even used this term.

On contrary to the view stated in the scientific literature that LC RSFSR of 1922 didn't contain records about limited proprietary land rights (Baturin, 2009), it was this code namely that introduced the notion "labour land usage". The land plots were provided on a continuing basis according to this right (art. 11).

The right of land usage allowed running the economic land usage by means, chosen by the user according to its discretion, and development and usage of constructions and buildings on the land for economic and residential demands (art. 24), at that all the constructions, buildings, planted areas, plants and everything connected with the land plot, which was in the usage of land-user, belonged to the user; thus the whole construction reminded emphyteusis on the part of land usage, and superficies on the part of possibility of building constructions on it.

The right of untimely usage was first provided in the Decree of the Presidium of the Supreme Council of USSR from 26.08.1948 "About the right of citizens on purchase and construction of the individual living houses" (Decree of the Presidium, 1948), according to which the allocation of the civil land plots both in the city and outside it for construction of the individual living houses is done in untimely usage.

In CC of RSFSR of 1964 the socialist system of economy and socialist property on the implements and means of production (paragr. 2 of art. 1) were proclaimed as the basis for proprietary relations in the soviet society. As A.L. Makovskii states this resulted in certain "primitivism" of civil-legal instruments: the property rent was popularized (first of all, cars) instead of gaining it into the property (Makovskii, 2010).

Properly speaking, the absence of legal regulation of any other proprietary right except for property became the result of such "simplification". Assuming the existence of operative management rights and some other rights of property owning by act of law or agreement (art. 157), CC of RSFSR of 1964 didn't discover its content.

In the Land Code of RSFSR of 1970 the right of continuing usage (untimely or temporary-art. 11) for individual living construction, gardening, personal back and cottage economy running and other aims was given in the provision development about labour usage most of all land legislation that was nothing else than limited proprietary right. The right of life hereditary owing of land plot appeared for the first time in art. art. 5, 20 of Fundamentals of Union of SSR legislation and allied republics about land of 1990, however this right was regulated scarcely enough.

In the Housing legislation Fundamentals of the Union of SSR and Allied republics of 1981, and then in the Housing Code of RSFSR of 1983, perhaps, for the first time in the soviet legislation the usufructural type rights as the rights of hirer family members (art. 26 of Fundamentals, art. art. 53 of 133 of HC), who gained the right of living premise usage equally with the hirer (owner) as a result of moving-in, were admitted as a matter of fact. However, this law didn't give any naming to these rights, and their content was disclosed very superficially.

Thus, in the soviet period the limited proprietary rights were not systematized; the law at all paid extremely a little attention to their legal regulation.

Only at the beginning of 90 s years of last century the proprietary rights in their understanding, closed to the classical one, again returned to the native legislation. In art. 5 of Law "On property in RSFSR" of 1990 the right of 
complete economic running, and operative management were called as the limited proprietary rights, and the article 6 of Law contained indication on the possibility of settlement of the limited proprietary rights by the other law.

Thus, the life hereditary land owing (art. 7), untimely (continuing) land plot usage, already known in the soviet legislation, and temporary land plot usage, different from the rent, in the Land Code of RSFSR of 1991 was introduced except for the property right.

The Civil Legislation Fundamentals of the Union of SSR of 1991, which Section II was called as "Property right and other proprietary rights" and that related to them the right of complete economic running (art. 47), operative management right (art. 48) and right of life hereditary land plot and other natural object owing and usage (art. 49) became the next stage in the development of proprietary rights.

The civil code of RS marked the new stage in regulation of the proprietary legal relations. Article 216 of RF CC relates to the limited proprietary rights the right of life hereditary land plot owing (article 265); right of continuing (untimely) usage of land plot (article 268); servitudes (articles 274, 277); the right of economic property owning (article 294) and right of operative property management (article 296). However, there are other proprietary rights, not provided directly by art. 216 of RF CC, for example, the right of usage of living premise in the family members of this premise owner. It is truly noticed in the works of Russian scientists that as the proprietary rights bear absolute character, it is important for all three parties to know its content, and so it must be determined by the law beforehand (Sukhanov, 2002).

It is the reason why increased attention of not only scientists, but the legislator either is drawn to proprietary rights modernization: in the project of RF CC that is under consideration of State Duma (Civil Code, 2012), the independent section consisting of 15 chapters is devoted the proprietary right.

The clause 2 of art. 223 gives the closed list of the limited proprietary rights: the right of continuing land owing (chapter 20); the right of real estate development (chapter 20.1); servitude (chapter 20.2); the right of personal usufruct (chapter 20.3); mortgage (chapter 20.4); the right of acquisition of other's immovable property (chapter 20.5); the right of item delivery (chapter 20.6); the right of operative management (chapter 20.7); the right of limited land plot owning (article 297.1). The system of proprietary rights, offered by the Project authors, highly reminds the Civil Code, developed by the author.

\section{Methodology}

\subsection{About Notion and Classification of the Limited Proprietary Rights}

The active legislation of RF doesn't disclose the notion of proprietary right, as well as legislation of almost all western countries-Italy, Spain, France, Сzech Кузгидшм=c, Switzerland, including as opposed to the very popular opinion (Basic Civil Law, 2009), it is absent in Germany. Articles 845 and 855 of GCC (German Civil Code) deals with the notion of owning as an actual domination over the item, at that exclusively for own benefits (German Civil Code, 2008), but it is obvious that the proprietary right is not exhausted by owning.

In art, 221 of the RF CC under reforming the proprietary right is determined as the right, which gives the direct domination over item to a person, and bases for collective or individual execution of authorities of its ownership, usage and disposal within the limits, specified by CC. The above-mentioned definition causes some issues. Ownership is literally determined in art. 209 of Project as direct domination over the item. It means that the proprietary right is the right that provides person with ownership and bases for ownership authority execution, in particular.

However the problem is much more serious than the terminological disputes and critical comments on determination of the proprietary right as "double owning" (critical comments on such approach are contained in the works of V.K. Reikher and are commonly known (Reikher, 2007)). This definition is contained neither in the scientific works, but in law, so particularly pragmatic issues must take the first place as "what does this definition give?" and "Does it allow us answering the question about possibility of qualification of the dispute legal relation as the proprietary or legally binding one?".

In the scientific literature the dispute about signs of proprietary rights, which allow differing them from the legally binding ones, has been held for long time already (Akhmet'ianova, 2011). The authors of Conception of the civil legislation development (hereinafter referred to as Conception) (Conception of Civil Russian, 2009) offer eight signs of the limited proprietary rights: a) proprietary rights appear and cease according to the bases, set by CC and laws published in accordance to it; $b$ ) the list of proprietary rights is determined exclusively by $\mathrm{CC} ; \mathrm{c}$ ) content of proprietary rights is determined by $\mathrm{CC}$; the order of their execution is determined by $\mathrm{CC}$ and laws published in accordance to it; $d$ ) the proprietary rights burden the item (property), provide the dominance over certain item 
(property) to the owners and follow by the item; e) the proprietary rights have the advantage over other proprietary rights on the corresponding item (property); f) the proprietary rights, as opposed to other subjective civil rights, are subjected to proprietary-legal protection; g) correlation of owner's authorities and possessor's limited proprietary right is determined by $\mathrm{CC}$ rules in accordance with proprietary right; $h$ ) proprietary rights on the immovable property are subjected to the state registration and appear from the day of such registration.

However the small part of these signs is not criteria; A.O. Rybalov writes truly: "The absence of legally established criteria, on which basis the right could be qualified as the proprietary one, led to that the place of signs was taken by the qualification consequences (the property of movement and absolute protection), as a result of which the practical meaning of proprietary right category has been lost" (Rybalov, 2007). Only domination over the item as the peculiar object of right and possibility to satisfy their interest without intermediary actions of other persons can be obviously called the indisputable signs of the proprietary right, on assumption of its nature.

Movement and absolute way of right protection, proprietary right priority, ability to burden item, publicity, determination of types and contents are not accidentally considered in the foreign doctrine and right of countries of continental Europe as the proprietary right principles, (Emelkina, 2010), i.e. are applied to the right that is qualified as the proprietary one.

The ideas of E.A. Sukhanov, who many times offered to fix the exhausting list of proprietary rights in the law (Mattei, 1999; Sukhanov, 2006), made essential effect on the legislator. The clause 2 of art. 223 of Project gives the closed list of the limited proprietary rights: the right of continuing land owning (chapter 20); the right of real estate development (chapter 20.1); servitude (chapter 20.2); the right of personal usufruct (chapter 20.3); mortgage (chapter 20.4); the right of acquisition of other's immovable property (chapter 20.5); the right of item delivery (chapter 20.6); the right of operative management (chapter 20.7); the right of limited land plot owning (article 297.1). This is good solution to situation, a strict reference point for practice; together with it, this solution has as minimum three shortages. First of all, it bears particularly temporary character as the constant complication of the public connection inevitably generates new relations, the parties to which aspire to receive protection.

Secondly, the closed list in any regulatory act means the highest level of codification as the court practice wouldn't be able to correct its shortages with the help of analogy. For example, in spite of the fact that in cl. 7.2 of Section IV of Conception the provision from the Roman law about that usufruct can be offered on the immovable property or movable property (see, for example, Dig. 7.1.7. Ulpian, Dig. 7.1.3.1., Guy and etc.) was placed, and in the Project only immovable items (art. 302.1 of Project) are called as the object of usufruct right. At that the usufruct appears on the basis of will, in particular, testamentary bequest. However, cl. 2 of art. 1137 of CC allows appearance on the basis of testamentary bequest of movable property, about which the art. 223 of Project doesn't remind. This means that on this stage the code suffers from insufficient systematization.

Thirdly, the closed list of limited proprietary rights extremely impedes the qualification of relations actually formed between the parties in disputable situations. We can take as an example the same usufruct, which is considered in two forms in the Project — ordinary and social one. The ordinary usufruct can be established on the contract, both refundable and non-repayable one, made in the simple writing form (cl. 2 art. 302.2 of Project). The issue about correlation of ordinary usufruct with certain legally-binding relations, in particular, with rent of living premise (commercial rent) is rightful one.

The correction of provision of chapter 35 is not provided by the Project. The basis of appearance of rent relations as well as one of the bases of ordinary usufruct is contract (art. 671 CC RF). The fact that the contract serves as the possible basis of appearance for relation of commercial rent contract can't be called the determining difference.

The content as the usufruct (cl. 1 of art. 302.3 of Project) and authorities at the hirer in the commercial rent contract consists of possession and usage of the item in accordance with its purpose (in the rent for living - art. 671 of CC that as a matter of fact is the same in this case). The rent is refundable (art. 628 of CC), usufruct is also can be refundable (this is essential condition of the contract - cl. 2 of art. 302.2 of Project). For example, both the hirer and usufructury have the protection of his right from all third persons, including the owner (cl. 1 of art. 302.3 of Project and art. 215 of Project). The presence of norms, which regulate the relations completely different according to their nature by very different ways, is hardly appropriate. In practice it leads to very unpredictable consequences, when as a result of shortages of legal techniques of the contract made by physical persons it will be impossible to define strictly, what legal relations are formed between them.

If in the West the regulatory acts are polished by ages of application, then in the Russian legislation, especially in the area of regulation of proprietary legal relations, there is no and can't be proprietary right succession as such one didn't existed in the soviet period. We should remember O. A. Krasavchikov, who already in 1958 stated: "recently the classification of civil legal relations into proprietary and legally-binding ones, subdivision, which is 
long since known in the legal science, is neglected... Obviously, the similar provision formed as a result of the fact that the science of civil law couldn't show the usefulness of the specified differentiation and place, where it can be used practically" (Krasavchikov, 1958). Today such "usefulness" is on hand and as a result the practice faced with the problem that they can't substantiate this differentiation.

It seems that the peculiar meaning belongs not only to the proprietary right, and its qualification signs. We think that it is necessary to exclude the notion of proprietary right from the future law text. We should not indicate on the closed list of the proprietary rights in the Project, and fears that the parties of the legally-binding legal relations can in this case create some proprietary right unknown for legislation (what they never made in the newest history), which can be levelled by the direct ban set on such agreements. The discussion about signs of the proprietary right should and must be prolonged on the doctrinal level, from which the practice will get bases for their conclusions and solution of concrete life situations.

\subsection{Servitudes}

In the most primary sense the servitude means duty, obligation - from the Latin servitus, that means "slavery, duty". In relation to this case, Heinrich Dernburg truly noticed: "Servitus is the Roman name both for servitudes and slavery. They both "serve" to the predominant subject. However, their legal nature is completely different" (Dernburg, 1905).

The appearance of servitude and its further distribution is inseparably connected with the private property. Explaining its origin, A.I. Kosarev justly marks that "with the growth of private property on the land and increase of the number of land plots, the cases, when the owner couldn't approach to its part except through the neighbour's plot, were not rare. Thus, the institute of country servitudes, i.e. the right to come or drive through the neighbour's plot, drive the cattle or pass the water off', was formed. (Kosarev, 1986)

The typical peculiarity of servitude, which differed it from the other rights of other's item usage, known to the Roman law, for example, from the hire, was that servitude was closer connected with the item, and its existence (reality) didn't put in dependence on the change of item owner, burdened by servitude, as it took place at the hire. The servitude was the burden of the item itself and together with it passed to any third party, which became owner of such thing. "When servitude was set on one estate for the benefit of other estate, - the Roman lawyer Pavel marks,- - then servitudes follow by the estate at selling" (D.8.4.12.) (Records of Roman Law, 1997). Hence it follows that the servitude represented the direct legal domination, independent on the third parties, over the item to the subject.

In the modern civil study of western states the servitude is traditionally divided into real (land, praedial) construction, established in relation to the land plot or located on it for using the plot or construction (for example, $\S \S 1018$-1029 GCC (German Civil Code, 2008), and personal one, which burden the land plot for the benefit of concrete person (\$\$1090-1093 GCC (German Civil Code, 2008)).

According to the content the servitudes are divided into the positive and negative ones. The civil legislation of the western states usually relate servitudes, fixing the right of a person to perform certain action to the detriment of owner: the right on riding, passing, driving of the cattle, water or pasture usage etc. to the positive ones, and the right of a person to require from the owner to refrain from the execution of the certain actions, for example, servitudes of light and air to the negative one (Vasiliev, 2008).

The institute of servitude was strictly designated for the first time in the Legal Civil Code of the Russian Empire (Legal Code, 1900). The Section II of book II of volume X called "About the essence and space of different property rights" and together with the property right considered the right of participation in usage and benefits of other's property. As a matter of fact, this participation can be considered as the servitude type right. The legal code distinguished the published servitudes (the general right of participation in the property benefits, established "for the benefit of all without withdrawal") and private (established "exclusively for the benefit of any of the private owners"- art. 433). The right of driving the cattle and its feeding (art. 435), the right of passing through the coastal lands (art. 437, 438) were related to the public servitudes (art. At that the Legal Code didn't differ servitudes and limited property rights in the public interests, for example, obligation of mill owners and bans of owners' lands, by which the small rivers flow, were established in the same section that the general right of participation in the property benefits).

The right of private participation is not separated from the neighbouring rights known today, which included the rights of land owners to demand from the neighbours to refrain from the water lifting, construction of dams and etc. (art. 442), the right of house master demand from the neighbours not to build ovens to the wall of its house, not to pour water and throw litter off etc. Moreover, the bans were provided without house master consent to locate 
windows in the house under construction in such a way that they would turn into the court or to the roof of earlier built house (art. 446).

The right of driving into the forest that included usage of timber and wood forest from the other's cottages exclusively for own demands can be also called servitude (art. 453-466 — pp. 29-30).

The further development of the servitude study was continued in the Project of Civil Code (Tyutryumova, 1910). Section IV “The patrimonial rights in other's property" in Book III of Volume 1 of Civil Code to patrimonial rights in the other's property, which were established only on the immovable property, related servitudes to them along with the hereditary tribute owning, right for mining and land cultivation, usufruct and right of proprietary deliveries (art. 917-918).

Repeating the provisions of art. 83 of GCC, art. 919 and 920 of the Project fixed the rule, according to which servitude appeared as a result of contract or will; at that in the first case - from the day of right registration (entry of the record in the patrimonial book), secondly - from the day of legacy opening, and independently on registration. The servitude was determined as a rule in other's estate, which impose on the owner of this estate obligation to bear something or not to do something (art. 994). The land and personal servitudes (art. 995) were known to the Project, at that as opposed to Section 2 in Part 4 in Book 3 of GCC (German Civil Code, 2008), that considered usufruct as a personal servitude, the Project took them as different institutes basically.

The Project related to servitude the open list of obligations to bear negative effect of neighbours - rolling the roof down in own yard, the right for light and view, the right to make balconies, which are turned to the neighbour's yard, and the right to deluge the neighbouring lands a little (art. 1006). At that the Project weakly differentiated the personal servitudes and usufruct right existing with it (art. 951-993). Thus, according to committee view, "the use owner has the exclusive right for all profits and benefits, that differs this right from the servitude one" (Tyutryumova, 1910), that didn't correspond to the Project text, as the Project related to the personal servitudes (art. 1019) the right of usage (i.e. extraction of fruits and other benefits from other's property in the size, necessary for satisfaction of person's demands, whom this right belongs - art. - 1022) and the right for dwelling (i.e. the right to live in the other's house or in its part, using all its services — art. 1023), the right of hunting, fishing in the other's estate (art. 1027). Also all land servitudes, which can bring benefit for the person, even if he didn't own the estate, were admitted as personal ones.

However, further these norms were not developed and didn't receive practical implementation. In the following seventy years the soviet legislation didn't regulate the servitude relations.

The notion of servitude returned to our legislation together with acceptance of the Part one of CC of RF. Presently the norms of Russian legislation about servitudes are scarce enough (art. 274 of RF CC, art. 23 of RF LC, art. 1 FL from 21.07.1997 No. 122-FL "About state registration of the rights on immovable property and deals with it" and don't answer to the practice demands. In the scientific literature the successful examples of servitude demand and non-imageness in their legal regulation at state immovable object construction, for example, in the course of preparation to the Winter Olympic Games in Sochi are given (Emelkina, 2010).

Namely because of this, the legislator, embodying the basic provision of Conception of civil legislation development, in the Project of RF Civil Code seriously reforms the servitude institute (Chapter 20.2 of Project of RF CC). In particular, this chapter specifies that servitude can be established between owners of predominant and subordinate items. At the same time in accordance with cl. 6 of art. 301 of Project of RF CC the owners of proprietary rights, which have authorities to use and own subordinate and (or) predominant items, are entitled to demand the servitude establishment. The current version of the RF Civil Code doesn't provide the closed list of concrete types of servitudes (cl. 1. art. 247 of RF CC), while the Project of RF CC contain the ban on creation of the new types of servitudes with listing all possible ones (cl. 5 art. 301 and $\S 2$ of chapter 20.2 of Project of RF CC).

\section{Results}

Thus, the analysis of the current legislation and practice of its application in the area of limited proprietary rights give us understanding about the extent of research work that should be done by the civil study experts for construction of distinct, consistent and scientifically substantiated system of proprietary rights.

We should understand a limited proprietary right (the right for others' things) as the absolute civil right in one or other relation limited by the law to use other's property for the own benefits without owner's participation. In the Soviet period such right almost was not regulated. It received its development in Russia only in the beginning of 90th years of XX century. Since that time the process of systematization of this civil-legal category has begun.

The Civil Code of RF became the important legal act in regulation of the proprietary legal relations. It doesn't expose the notion of proprietary right that is typical for legislation of many western countries. However, the 
incomplete classification of the limited proprietary rights appeared in it. The legislator considered and fixed not all proprietary rights. At the same time the scientific world many times emphasized the importance of full classification, as the proprietary rights bear absolute character. Their content must be determined by the law in advance.

Such situation led to that in the Civil Code project of RF we see considerable positive changes of the list, content and regulation of proprietary rights. In this act the individual section consisting of 15 chapters is devoted to the proprietary right. It is important to emphasize that cl. 2 of art. 223 of Project gives the closed list of proprietary rights, which corresponds to the current legal activity. It is the right vector of legislation development in this issue and distinct reference point for practice. At the same time a closed list means high level of codification in order to exclude ambiguity in the court practice. We face with that insufficient systematization is peculiar to the Project. It will cause disputes between parties of legal relations.

We come to understanding that not the notion of proprietary right itself has the peculiar meaning, but its qualifying signs. It is necessary to exclude the notion of proprietary right from the Project text of CC of RF and also don't point out on the closed list of proprietary rights. As there is no succession in the area of proprietary legal relation regulation in the Russian legislation, it is necessary to use developments of the western countries.

\section{References}

Akhmet'ianova, Z. A. (2011). The proprietary right. Moscow: Statut.

Author. (1900). Legal Code of the Russian Empire. Saint Petersburg.

Author. (1997). The Records of Roman law: Laws of XII tables. Moscow.

Author. (2008). German Civil Code. M.: Wolters Kluwer Russia.

Author. (2009). Conception of Civil Russian Federation Legislation Development. Digest of Higher Attestation Commission of Russian Federation, 11, 6-99.

Author. (2009). The Basic Civil Law Institutes Of Foreign Countries. Moscow: NORMA.

Author. (2012). Civil Code of the Russian Federation. Received from RLS "ConsultantPlus".

Baturin, V. A. (2009). The system of limited proprietary rights in the modern civil legislation. Krasnodar: Konti-Press.

Danilova, E. V. (2008). The disputable issues of property right development in the Russian pre-revolutionary legislation. The journal of the Russian right, 10, 139-147.

Decree of the Presidium of the SC of USSR. (1948). About the right of citizens on purchase and construction of the individual living houses. Bulletin of SC of USSR, 36.

Dernburg, G. (1905). Pandects. Proprietary right. Saint Petersburg.

Emelkina, E. A. (2010). The system of limited proprietary rights on the land areas. Moscow: Statut.

Emelkina, I. A. (2010). The notion and signs of proprietary right in the Russian and Foreign civil study. Notarius, 6,39 .

Kamyushankii, V. P. (2000). The scopes and limitations of the property right. Volgograd: Uchitel.

Kosarev, A. I. (1986). The Roman law. Moscow: Yuridicheskaya literatura.

Krasavchikov, O. A. (1958). Legal facts in soviet civil right. Moscow: Gosyurizdat.

Kurdinovskii, V. I. (1899). To study of the legal right property limitation on the immovable property in Russia. Odessa.

Makovskii, A. L. (2010). About codification of civil law (1922-2006). Moscow: Statut.

Mattei, U. (1999). The basic provision of property right. Moscow: Yurist.

Meyer, D. I. (1864). The Russian Civil Right. Saint Petersburg.

Reikher, V. K. (2007). The absolute and relative rights (to the problem of division of economic rights). Particularly in relation to the soviet right. The digest of civil law, 2(7), 144-204.

Rybalov, A. O. (2007). The limited proprietary rights: the problems of determination. Zakon, 2, 120.

Sukhanov, E. A. (2002). The notion and types of limited proprietary rights. The digest of Moscow University, $11(4), 3$. 
Sukhanov, E. A. (2006). About notions and types of proprietary rights in the Russian civil law. Journal of Russian law, $12,42$.

Tyutryumova, I. M. (Ed.). (1910). Civil Code Project. Saint Petersburg.

Vasiliev, E. A., \& Komarov, A. S. (Ed.). (2008). Civil and Trade Right of Foreign States. Moscow.

\section{Copyrights}

Copyright for this article is retained by the author(s), with first publication rights granted to the journal.

This is an open-access article distributed under the terms and conditions of the Creative Commons Attribution license (http://creativecommons.org/licenses/by/3.0/). 